Gastroia: Journal of Gastronomy and Travel Research, Vol. 5, Issue 3, 505-521, 2021

The Effect of Food Safety and Hygiene Education on the Knowledge Levels of Tourism Students Öznur CUMHUR

\title{
THE EFFECT OF FOOD SAFETY AND HYGIENE EDUCATION ON THE KNOWLEDGE LEVELS OF TOURISM STUDENTS
}

* Öznur CUMHUR

\section{GAS}

Yayin Bilgileri

Kabul tarihi: 30.03.2021

Yayın tarihi: 08.09.2021

Yazar İletişim Bilgileri

* oznur.cumhur@bilecik.edu.tr

\begin{abstract}
This study aims to reveal the effect of food safety and hygiene lesson on the food safety knowledge level of the students studying in the tourism management department. The lesson has included hygiene, sanitation and food safety concepts, hygiene and sanitation in tourism businesses, personal hygiene, microbiological, physical and chemical degradation of foods, food safety systems. Questionnaire consisting of a total of forty questions on food and foodborne diseases, personnel hygiene, kitchen and equipment, contamination, temperature control, and food preservation was used as a data collection tool. The study was administered to tourism management and hospitality undergraduate students studying in Bilecik Seyh Edabali University. Students had the lowest range of food safety knowledge about temperature control and food preservation $(20.6 \%-89.2 \%)$ on temperature control and food preservation before the food safety and hygiene lesson. In other groups, students showed a level of knowledge in the average $86.5 \%-92.8 \%$ range. The lesson showed a significant difference in all parts regarding the level of food safety knowledge. Overall, the current study has shown that gaps in food safety knowledge can be overcome with food safety and hygiene lesson.
\end{abstract}

Keywords: Food Safety, Hygiene, Food and Beverage Establishments 


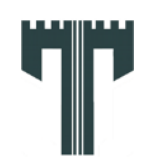

Gastroia: Journal of Gastronomy and Travel Research, Vol. 5, Issue 3, 505-521, 2021

The Effect of Food Safety and Hygiene Education on the Knowledge Levels of Tourism Students Öznur CUMHUR

\section{INTRODUCTION}

An estimated 600 million people get sick due to unhealthy food consumption in the world, while 420000 people die every year (World Health Organization [WHO], 2017). In Turkey, 77515 cases of foodborne disease were identified in 2000 (WHO, 2004). However, this only represents the visible part of a big problem due to the lack of adequate reporting and sharing of foodborne illnesses in Turkey. While foodborne diseases threats global health, they also harm the tourism industry. Providing food safety and hygiene in all its dimensions is one of the indispensable factors for fragile service sectors such as tourism. According to the 2018 report of the European Food Safety Authority and the European Centre for Disease Prevention and Control, approximately $28 \%$ of the number of cases in foodborne outbreaks in the European Union countries were detected in restaurants, cafes, bars, pubs, hotels, and caterings (European Food Safety Authority and European Centre for Disease Prevention and Control, 2019). Similarly, 841 foodborne outbreaks reported to the Centers for Disease Control and Prevention in the United States caused 14481 diseases, and $41 \%$ of these diseases were associated with restaurants, $29 \%$ with food or banquet facilities, and $2 \%$ with hotels (Centers for Disease Control and Prevention, 2017). It has been known that most foodborne diseases and outbreaks around the world are caused by poor compliance with food procedures, such as preparing, cooking, and storing food in such places and homes (Gould, Rosenbulum, Nicholas, Phan and Jones, 2013). There is a consensus that trained food workers are needed to minimize foodborne illness and protect public health (Tuncer ve Akoğlu, 2020).

Food and beverage businesses such as restaurants, hotels, pubs and bars which are an important part of the tourism sector, are the places that employ a lot of employees and where the most common food production and service are performed. Therefore, food safety, hygiene, and sanitation in these enterprises is one critical issue that should be taken into account by the managers. In order to prevent foodborne diseases at these points, managers and employees should have knowledge about food safety and hygiene in the food and beverage department and pay attention to the creation of hygienic conditions. In the literature, there are many studies on the knowledge, attitudes and practices of those working in food and beverage departments and hotel kitchens (Baş, Ersun and Kıvanç, 2006; Başer, Abubakirova, Şanlıer and Çi1, 2016; Sanlıer, Cömert and Durlu-Özkaya, 2010; Sanlıer, Sormaz and Güneş, 2020; Smigic et al., 2016; Tuncer and Akoğlu, 2020; Ünlüönen and Cömert, 2013) and university students studying in the field of health and food (Ertopcu, Avcıkurt, and Çetinkaya, 2019; Giritlioğlu, Batman and Tetik, 2011; Hertzman, Kitterlin, Farrish and Stefanelli, 2011; Luo et al., 2019; Marklinder et al., 2020; Ozilgen, 2010; Stratev et al., 2017). However, there is no comprehensive study on food safety and hygiene education of tourism management students, especially in connection with the tourism sector. From this point of view, it is important to evaluate the level of knowledge and education about food safety and hygiene issues in the education process of tourism management undergraduate students, who can take part in all levels of the food and beverage sector. The effect of food safety and hygiene education on food safety knowledge of tourism management students was evaluated in this study. In addition, this study will provide a forecast for improving the content of hygiene, sanitation, and food safety lessons to be given in tourism management departments. It is thought that the study will contribute to the 
Gastroia: Journal of Gastronomy and Travel Research, Vol. 5, Issue 3, 505-521, 2021

The Effect of Food Safety and Hygiene Education on the Knowledge Levels of Tourism Students Öznur CUMHUR

literature, future research on food safety and public health, and the determination of training needs in the relevant departments.

\section{CONCEPTUAL FRAMEWORK}

The tourism sector is in search of trained and qualified employees in the units where food production and service carried out, as in all areas. Therefore, while food safety, hygiene, and sanitation are among the most critical issues that employees in the tourism sector should know and pay attention to; risky food safety behaviour is emerging as a major problem in the tourism industry. In studies of food safety knowledge, attitudes, and practices for employees in the hotel kitchens and food and beverage departments in Turkey it is often highlighted shortcomings in this matter and the adequacy and effectiveness of the food safety training have been questioned (Sanlıer et al., 2010; Sanlıer et al., 2020; Tuncer and Akoğlu, 2020). Food safety education should be related to applications for the field, be appropriate to the type and conditions of the activity and include current food safety problems in its content. It is emphasized that while giving food safety training to individuals, it is necessary to provide specific information and strong arguments that meet their needs by considering the restrictive factors in the relevant field (Fraser and Miller, 2014; Jackson-Davis, Olsen, Chapman, Raymond and Chaifetz, 2015). It is necessary not only to focus on theoretical elements but also to include reflective examples to improve knowledge for effective food safety education (Lange, 2017). Thus, food safety messages are transmitted reliably, and individuals are encouraged to adopt practices aimed at preventing foodborne diseases.

At this stage, knowledge and attitudes about food safety and hygiene gain importance among tourism managers who will work in the tourism sector or supervise employees in preparing and selling food and beverages. In a study with program directors to identify food safety education goals for hospitality management students, hospitality educators rated food safety competencies as very important. However, it was determined that $28 \%$ of the hospitality educators participating in the survey did not consider the food safety certificate necessary for graduation, $25 \%$ considered it optional and only $45 \%$ considered it necessary for graduation (Scheule, 2000). The fields of hygiene, sanitation, and food safety to students in undergraduate tourism education are given related lessons in some universities in Turkey. The continuity of foodborne diseases and the fact that the production areas, which are mostly included in the tourism industry, form the basis of this problem, revealed the need for more research on this issue.

In general, certain studies on employees of the food establishments or university students in Turkey yielded various results regarding the food safety knowledge levels and the effect of knowledge and education on attitudes and behaviours (Baş et al., 2006; Giritlioğlu et al., 2011; Ertopcu et al., 2019; Ozilgen, 2010; Sanlier and Tunç, 2008, Sanlier et al., 2010; Sanlier et al., 2020; Tuncer and Akoğlu, 2020; Ünlüönen and Cömert, 2013). Sanlier et al. (2020) concluded that especially long-term trainings cause a positive change in knowledge, attitudes and practices on food safety and hygiene, and the permanence of the information is better. There is only one study evaluating the effect of foodservice education, food safety training program, and food safety work experience for university students, including hotel administration students, on students' knowledge, attitudes, and practices regarding food safety (Hertzman et al., 2011). Hertzman et al. (2011) evaluated the effects of foodservice 
Gastroia: Journal of Gastronomy and Travel Research, Vol. 5, Issue 3, 505-521, 2021

The Effect of Food Safety and Hygiene Education on the Knowledge Levels of Tourism Students Öznur CUMHUR

education, a special food safety certificate program, and food safety work experience on university students' knowledge, attitudes and practices towards food safety. They found that there was an increase in food safety knowledge based on training, but little difference in food safety practices. However, there is no other study that specifically examines the knowledge levels of students on food safety and hygiene in the tourism departments of the university.

\section{METHODOLOGY}

\subsection{Design}

First, "Tourism Management" and "Tourism and Hotel Management" departments that education at the undergraduate level was detected on the website of the Council of Higher Education in Turkey. Later, the education programs at the undergraduate level of these departments at universities in Turkey were studied from their official site. Compulsory and elective lessons covering topics related to hygiene, sanitation, and food safety were evaluated quantitatively.

In the second stage of the study, there is a survey study about food safety knowledge. Tourism management, tourism management, and hospitality education are given in 76 faculties and colleges in Turkey. The students studying in these schools constitute the target population of the study. The sample of this research consists of 3rd-year Tourism and Hotel Management students studying at Bilecik Şeyh Edebali University, Faculty of Applied Sciences between 2016-2019. The department has a total of 114 students taking the course during these semesters. The research was conducted among 102 students studying in the relevant department during the period between September 2016-December 2019. A questionnaire was applied before and after the "Food Safety and Hygiene" lesson, which tourism management students took 42 hours ( 3 hours x 14 weeks) in the fifth term. The lesson has included hygiene, sanitation and food safety concepts, hygiene and sanitation in tourism businesses, personal hygiene, microbiological, physical and chemical degradation of foods, food safety systems. A questionnaire was conducted before and after the "Food Safety and Hygiene" lesson, in which tourism management students took 42 hours in the fifth semester. The questionnaire took approximately $20 \mathrm{~min}$ to administer.

\subsection{Questionnaire}

Research data were collected through the questionnaire form, which was created using previous studies and various sources related to the subject (Artık, Şanlıer and Sezgin, 2017; Ozilgen, 2011; Sanlier et al., 2010). The reliability of the questionnaire was tested via the Kuder-Richardson 20 and has a reliability coefficient of 0.745 . The questionnaire form consists of two parts. The first part is the demographic characteristics section that determines the characteristics of the students participating in the study such as gender, age, and the high school they graduated from. The second part consists of a total of 40 questions that examined students' knowledge of contamination (6 items), food and foodborne disease (10 items), kitchen and equipment ( 7 items), personnel hygiene ( 8 items), and temperature control and food preservation (9 items) issues. Each question in the questionnaire was asked to be answered with two options, true and false. 


\begin{abstract}
T
Gastroia: Journal of Gastronomy and Travel Research, Vol. 5, Issue 3, 505-521, 2021

The Effect of Food Safety and Hygiene Education on the Knowledge Levels of Tourism Students Öznur CUMHUR
\end{abstract}

\title{
3.3. Data Analysis
}

The collected data were analysed using IBM SPSS Statistics 22.0 and Microsoft Excel Office 365 . The responses were evaluated as correct and incorrect answers. The expressions created to determine the hygiene knowledge levels were presented as average and percentage according to the answers given by the students. Paired samples T-Test was conducted to determine whether there was a significant difference in terms of taking the lesson. Independent samples T-test was used to evaluate the pre-lesson hygiene and food safety knowledge level for the high school variable of graduation. The level of significance was determined as $\mathrm{p}<0.05$ in the analyses.

\section{RESULTS}

In Turkey, "Tourism management" and "Tourism Management and Hospitality" departments continue their education at the undergraduate level in 76 faculties and colleges in 2020 (Council of Higher Education, 2020). In this content, hygiene, sanitation, and food safety lessons are included in a total of 31 tourism-related departments $(40.8 \%), 23$ of which are elective and 8 are compulsory in Turkey. Such lessons generally aim to provide students with information about the hygiene and sanitation rules, possible risk factors, and precautions that they should pay attention to in the preparation and service of food prepared and/or served by tourism enterprises. More than half of the departments do not have a separate lesson on hygiene, sanitation, and food safety.

The demographic profile of the students is given in Table 1. The study was applied to 102 tourism management students (51 females, 51 males) who took the food safety and hygiene lesson at Bilecik Seyh Edebali University. 30.4\% of the participating students $(\mathrm{n}=31)$ were $19-20$ years old, $57.8 \%(\mathrm{n}=59)$ were $21-22,10.8 \%(\mathrm{n}=11)$ were $23-24$ years old, and $1 \%$ $(\mathrm{n}=1)$ were 26 years old. When the type of high school the students graduated from is examined, $49 \%(n=50)$ of the students are from vocational high schools related to tourism or food and beverage and $51 \%(\mathrm{n}=50)$ of them are from other high schools. 
Gastroia: Journal of Gastronomy and Travel Research, Vol. 5, Issue 3, 505-521, 2021

The Effect of Food Safety and Hygiene Education on the Knowledge Levels of Tourism Students Öznur CUMHUR

Table 1. Demographic data of student to the food safety knowledge survey

\begin{tabular}{lc}
\hline Gender & $\begin{array}{c}\text { Percentage } \\
\text { (number of students) }\end{array}$ \\
Female & $50 \%(51)$ \\
Male & $50 \%(51)$ \\
\hline Age (years) & \\
$19-20$ & $\% 30.4(31)$ \\
$21-22$ & $\% 57.8(59)$ \\
$23-24$ & $\% 10.8(11)$ \\
$25-26$ & $\% 1(1)$ \\
\hline Type of High School Graduated & $\% 49(50)$ \\
High Schools Related to Tourism or Food and Beverage & $\% 51(52)$ \\
Others & 102 \\
\hline Total (n) & \\
\hline
\end{tabular}

The incorrect answers given by the students to the true and false information statements were scored as 0 , and the correct answers as 1 . The percentage of correct answers for each statement was calculated. While students gave correct answers in the range of $25-39(62.5 \%$ $-97.5 \%)$ at the beginning of the term, they gave correct answers in the range of $33-40(82.5 \%$ $-100 \%$ ) at the end of the term, after taking the lesson. At the end of the term, $20.6 \%$ of the students answered all questions correctly, while $70.6 \%$ gave correct answers to $95 \%$ or more of the questions (number of correct answers $\geq 38$ ).

With the questionnaire conducted before the lesson was given, it was revealed that there were gaps in some subjects regarding the food safety knowledge of the students. Table 2 shows the average correct responses and the percentage distribution of tourism management students who gave correct answers before the lesson, and the students in the related department who successfully completed the "Food Safety and Hygiene" lesson after the term. The percentage of correct answers before the food safety and hygiene lesson varied between $20.6 \%$ and $100 \%$, and the average knowledge level was $85.8 \pm 14.2$. Different results were obtained in studies conducted in the context of food safety and hygiene knowledge for students from different disciplines. In a study evaluating the food safety knowledge of university students in Turkey, students who specialize in health and food with face-to-face education were compared with students studying outside these fields. Food safety knowledge of students in departments related to food and health was found to be $78.46 \%$ on average, while the food safety knowledge level of students from departments other than food and health was 59.91\% (Ozilgen, 2011). Similarly, Stratev et al. (2017) determined that the food safety knowledge of veterinary students in Bulgaria was $85.06 \%$. It is seen that students who receive education about health and food have an interest in food safety and have a higher level of knowledge (Ozilgen, 2011; Stratev et al., 2017). In this sense, a part of the participant students that makes up our sample is a group that somehow contacts with food and beverages. The fact that students' food safety knowledge levels are not very bad before the lesson is due to the fact that almost half of the students (49\%) come from vocational high schools related to tourism or food and beverage. It was revealed that 
Gastroia: Journal of Gastronomy and Travel Research, Vol. 5, Issue 3, 505-521, 2021

The Effect of Food Safety and Hygiene Education on the Knowledge Levels of Tourism Students Öznur CUMHUR

there is a significant difference between the high schools they graduated from and the prelesson food safety knowledge of the students participating in the study ( $p<0.05)$. In Turkey, students from related vocational high schools receive basic level hygiene and sanitation education within the scope of some of their high school lessons.

Table 2. Food safety knowledge responses of tourism management students $(n=102)$

\section{Questions}

Correct Responses Mean \% (n)

Before Lesson After Lesson

\section{Food and Foodborne Diseases}

Food safety is important for the health of society.

$100.0 \%(102) \quad 100.0 \%(102)$

Safe food is a food that is suitable for consumption by removing all kinds of spoilage and contamination factors.

$93.1 \%(95) \quad 99.0 \%(101)$

All microorganisms cause food poisoning*

$86.3 \%(88) \quad 98.0 \%(100)$

Clean and healthy water with necessary laboratory controls

should be used in food production areas.

$98.0 \%(100) \quad 99.0 \%(101)$

Before preparing vegetables and fruits, they should be washed under plenty of running water.

Consuming raw milk or eggs is healthier and more nutritious than pasteurized milk or cooked eggs. *

Cracked or broken eggs can be purchased and used. "

$97.1 \%(99) \quad 100.0 \%(102)$

If the can is bulging and dented, the food in it should never be used.

There is no risk of any disease from consuming raw eggs and milk. *

\section{$62.7 \%(64) \quad 91.2 \%(93)$}

$95.1 \%(97) \quad 100.0 \%(102)$

$80.4 \%(88) \quad 100.0 \%(102)$

$88.2 \%(90) \quad 96.1 \%(98)$

After removing the mouldy part of foods, the intact part $\quad 73.5 \%(75) \quad 98.0 \%$ (100) should be used. *

Average Food and Foodborne Diseases Knowledge Level

$87.5 \%$

$98.1 \%$

\section{Personnel Hygiene}

All personnel working in the food production area are

carriers of microorganisms and may contaminate the food.

Personnel should use separate shoes and clothing in the

Personnel working in the food industry should pay attention to their personal hygiene for food safety.

There is no objection for the personnel working in the food 
Gastroia: Journal of Gastronomy and Travel Research, Vol. 5, Issue 3, 505-521, 2021

The Effect of Food Safety and Hygiene Education on the Knowledge Levels of Tourism Students Öznur CUMHUR

Disposable gloves should be used during service and no food should be touched with bare hands.

No microorganisms can be transmitted to food from the personnel in the kitchen and service area, who have no disease and are healthy. *

Personnel with illnesses such as diarrhoea, cold, flu should not be employed in food production and service areas.

Hands should be washed with warm running water and disinfectant soap after handling raw meat and vegetables.

Average Personnel Hygiene Knowledge Level

\section{Kitchen and Equipment}

Grounds of the food production and service areas should be smooth, well-maintained, and kept dry.

Service personnel should not hold the spoons, forks and knives by the mouth parts.

Cleaning materials and food should be stored separately.

The dishwashing place should be within the food preparation area in the kitchen.

For pest and rodent control in food establishments, professional assistance should be taken from a specialist and experienced company.

It should be avoided to have unreachable points in the kitchen in terms of cleaning.

Scratched Teflon and melamine containers can be used for food storage. "

Average Kitchen and Equipment Knowledge Level

\section{Contamination}

Counter, knives, clothes are factors of cross-contamination to food.

Raw and cooked food should not be stored together.

Meals that are not consumed after the service should not be served by heating for consumption and discarded.

Preparation of food groups such as meat, vegetables, and pastries should be on separate counters in the kitchen.

There is no risk in preparing raw and cooked foods on the same counter. *

There is no risk in mixing a previously cooked meal with a freshly cooked meal. *
$96.1 \%(98) \quad 98.0 \%(100)$

$94.1 \%(96) \quad 96.1 \%(98)$

$95.1 \%(97) \quad 100.0 \%(102)$

$83.3 \%(85) \quad 94.1 \%(96)$

$92.8 \%$

$97.3 \%$

$95.1 \%(97) \quad 96.1 \%(98)$

$83.3 \%(85) \quad 93.1 \%(95)$

$82.4 \%(84) \quad 88.2 \%(90)$

$92.2 \%(94) \quad 98.0 \%(100)$

$99.0 \%(101) \quad 100.0 \%(102)$

$96.1 \%(98) \quad 98.0 \%(100)$

$88.2 \%(90) \quad 98.0 \%(100)$

$90.9 \%$

$95.9 \%$

$88.2 \%(90) \quad 96.1 \%(98)$

$86.3 \%(88) \quad 94.1 \%(96)$

$76.5 \%(78) \quad 87.3 \%(89)$

$85.3 \%(87) \quad 96.1 \%(98)$

$86.3 \%(88) \quad 100.0 \%(102)$

$91.2 \%(93) \quad 100.0 \%(102)$ 
Gastroia: Journal of Gastronomy and Travel Research, Vol. 5, Issue 3, 505-521, 2021

The Effect of Food Safety and Hygiene Education on the Knowledge Levels of Tourism Students Öznur CUMHUR

\begin{tabular}{|c|c|c|}
\hline Average Contamination Knowledge Level & $85.6 \%$ & $95.6 \%$ \\
\hline \multicolumn{3}{|l|}{ Temperature Control and Food Preservation } \\
\hline Frozen foods should be stored at $-18^{\circ} \mathrm{C}$. & $87.3 \%(89)$ & $94.1 \%(96)$ \\
\hline Microorganisms are killed by freezing food. * & $54.9 \%(56)$ & $76.5 \%(78)$ \\
\hline Refrigerator temperature slows down the microbial growth. & $78.4 \%(80)$ & $96.1 \%(98)$ \\
\hline Pasteurization and sterilization are the same things. ${ }^{*}$ & $86.3 \%(88)$ & $98.0 \%(100)$ \\
\hline $\begin{array}{l}\text { Cold foods such as milk desserts should be kept below } 10 \\
{ }^{\circ} \mathrm{C} \text { until and during service. }\end{array}$ & $89.2 \%(91)$ & $91.2 \%(93)$ \\
\hline $\begin{array}{l}\text { Hot meals should be kept at a temperature of at least } 65^{\circ} \mathrm{C} \\
\text { until and during service. }\end{array}$ & $75.5 \%(77)$ & $96.1 \%(98)$ \\
\hline $\begin{array}{l}\text { Frozen food can be defrosted on the kitchen counter at } \\
\text { ambient temperature. }\end{array}$ & $20.6 \%(21)$ & $71.6 \%(73)$ \\
\hline Frozen food can be refrozen after dissolving. ${ }^{*}$ & $87.3 \%(89)$ & $98.0 \%(100)$ \\
\hline $\begin{array}{l}\text { Egg foods, dairy foods, meat, and meat products should not } \\
\text { be kept at room temperature. }\end{array}$ & $84.3 \%(86)$ & $90.2 \%(92)$ \\
\hline $\begin{array}{l}\text { Average Temperature Control and Food Preservation } \\
\text { Knowledge Level }\end{array}$ & $73.7 \%$ & $90.2 \%$ \\
\hline
\end{tabular}

* Sentences indicate the incorrect expressions

The percentage of students who gave correct answers after taking the lesson varied between $71.6 \%$ and $100 \%$. Before and after the lesson, the food safety information of food and foodborne diseases, personnel hygiene, kitchen and equipment, contamination, temperature control and food storage departments are presented in Table 3 on average with standard deviation (SD). In order to prevent food-borne diseases, it is important for tourism management students and graduates who will work in the kitchens of hotels and food and beverage businesses and in the service, which is the point of contact with food, have a certain level of knowledge about food safety and hygiene. Food safety knowledge level before and after the lesson showed a significant difference in all departments $(\mathrm{p}<0.05)$. After taking the lesson, the correct answers given by the students to the questions increased from $85.8 \%$ to $95.4 \%$ on average. 
Gastroia: Journal of Gastronomy and Travel Research, Vol. 5, Issue 3, 505-521, 2021

The Effect of Food Safety and Hygiene Education on the Knowledge Levels of Tourism Students Öznur CUMHUR

Table 3. The average level of knowledge before and after food safety and hygiene lesson according to the group of questions

\begin{tabular}{llll}
\hline \multirow{2}{*}{ Groups of Questions } & \multicolumn{2}{c}{ Correct Responses Mean\% \pm SD } & \\
\cline { 2 - 3 } & Before Lesson & After Lesson & \multirow{2}{*}{ p-value } \\
\hline Food and Foodborne Diseases & $87.5 \pm 12.1$ & $98.1 \pm 2.8$ & $0.009^{*}$ \\
Personnel Hygiene & $92.8 \pm 5.7$ & $97.3 \pm 3.3$ & $0.014^{*}$ \\
Kitchen and Equipment & $90.9 \pm 6.4$ & $95.9 \pm 4.0$ & $0.014^{*}$ \\
Contamination & $85.6 \pm 4.9$ & $95.6 \pm 4.7$ & $0.000^{*}$ \\
Temperature Control and Food & $73.7 \pm 22.6$ & $90.2 \pm 9.6$ & $0.010^{*}$ \\
Preservation & & & $0.000^{*}$ \\
\hline Average Food Safety Knowledge Level & $85.8 \% \pm 14.2$ & $95.4 \% \pm 6.1$ & \\
\hline " $p<0.05$ & & &
\end{tabular}

\subsection{Food and Foodborne Disease}

Managers and employees of businesses where food and beverage production take place must be knowledgeable and conscious about food and foodborne diseases for safe food production and service. After the lesson, the average knowledge level of the students about food and foodborne diseases is the highest with $98.1 \%$ compared to other fields. All students are aware that food safety is important for a healthy society. Interestingly, $62.7 \%$ of our students think that consuming raw milk or eggs is healthier and more beneficial than pasteurized milk or cooked eggs, while $88.2 \%$ of our students think that consuming raw eggs and milk does not pose any disease risk. Unfortunately, this also means that $11.8 \%$ of students are unaware of the potential dangers of raw milk and eggs, and $37.2 \%$ find raw milk and eggs healthier. When evaluated in terms of milk, milk is not sold on the streets in developed countries. However, $45 \%$ of the milk produced in Turkey in 2019 unlawfully took place in the informal sector. This value shows that although it is forbidden, milk continues to be sold on the streets (Mert, Artık, Dellal and Şireli, 2020). In addition, a study conducted in Turkey's province; $47.8 \%$ of consumers find their consumption of raw milk healthier and about $70 \%$ of consumers buy milk from street vendors (Çebi, Özyürek and Türkyılmaz, 2018). In general, the presence of this tendency makes it difficult to record milk production and consumption, and affects hygiene thinking on this subject.

After taking the lesson, $96.1 \%$ of students learned about the potential danger in these raw foods, but still $8.8 \%$ of students consider raw milk and eggs healthy. In another study conducted with university students, $78 \%$ of students in the health or food department group stated that drinking raw egg is highly risky for food poisoning, while students in the nonhealth or non-food departments answered this question correctly at a lower rate (57.4\%) and similarly, this situation has been identified as an information gap (Ozilgen, 2011). In order to avoid diseases caused by raw food, there is a need to focus on the hazards of raw animal products and put more emphasis on possible hazards in this regard. Other findings regarding food and foodborne illness are that $26.5 \%$ of students do not know that eating intact mouldy food is dangerous, and $19.4 \%$ of students do not know that bulging or dented can is 


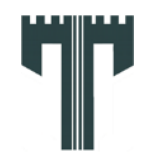

Gastroia: Journal of Gastronomy and Travel Research, Vol. 5, Issue 3, 505-521, 2021

The Effect of Food Safety and Hygiene Education on the Knowledge Levels of Tourism Students Öznur CUMHUR

dangerous for canned foods. After the lesson, 98-100\% of students were aware of the dangers of mouldy foods or deformed canned food. When evaluated in general, it has been determined that culinary program students are as knowledgeable about food and food-borne diseases as tourism students (Ertopçu et al., 2019).

\subsection{Personnel Hygiene}

Deviation of personnel from health and hygiene protocols is shown as regular sources of food-borne outbreaks in food and beverage businesses (Clayton, Clegg Smith, Neff, Pollack and Ensminger, 2015). In this context, the personnel hygiene section focuses on health and hygiene practices such as personal care, hand washing, use of gloves, use of accessories, use of personal shoes and clothes, and involvement in work while sick. Students' knowledge of personnel hygiene group was at a higher level (92.8\%). All students knew those food employees should pay attention to their personal hygiene for food safety, but there was a lack of knowledge about hygienic practices (washing hands after contact, etc.) that pose a risk of cross-contamination, and that personnel is a source of microorganisms.

$83.3 \%$ of the students were aware that hands should be washed with disinfectant soap and warm running water after handling raw meat and vegetables. The research findings show that $16.7 \%$ did not have this information about hand hygiene, but the rate of not knowing after the lesson period decreased to 5.9\%. More than $95 \%$ of the students knew that they should use separate shoes and clothing in the food production area and that they should not work in the food production and service area in case of illness such as diarrhoea, cold, and flu. Similarly, in studies conducted for kitchen staff in hotel establishments in Turkey, it has been determined that many employees are conscious about changing clothes and disease (Sanlıer et al., 2010; Ünlüönen and Cömert, 2013). However, 8.88\% of the participants thought that not all personnel, even if they were healthy, are carriers of microorganisms, and therefore it was determined that they had insufficient information about the contamination of food by microorganisms originating from the personnel. Similar to the finding obtained, Ünlüönen and Cömert (2013) showed that 7.3\% of hotel kitchen employees have insufficient knowledge about the microorganism carrier of the personnel and contamination. Giritlioglu et al. (2011) reported that fewer culinary students (72\%) knew the information that bacteria causing food poisoning were not carried only by sick people. In this context, it is important to know the sources of contamination of food, as well as the hygiene practices that the personnel should do, and to learn how to prevent contamination with the measures taken and the hygiene practices.

\subsection{Kitchen and Equipment}

Ensuring food safety cannot be evaluated separately from the environment where food is stored, produced, and serviced. The kitchen where food is produced, and the hygiene and usage patterns of tools and equipment used in the preparation, cooking, service of food and beverage affect food safety. Regarding the kitchen area, $92.2 \%$ of the students knew that the dishwashing area should not be in the food preparation area, $96.1 \%$ knew that there should not be unreachable points in terms of cleaning in the kitchen. After the training, these information rates increased to $98 \%$. However, knowledge about the application in the kitchen or the use of kitchen equipment was known at a lower level. For example, $17.6 \%$ of 


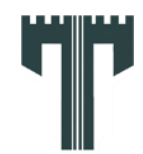

Gastroia: Journal of Gastronomy and Travel Research, Vol. 5, Issue 3, 505-521, 2021

The Effect of Food Safety and Hygiene Education on the Knowledge Levels of Tourism Students Öznur CUMHUR

the students did not think that cleaning materials should be stored separately and that there is a possible chemical hazard. Sanlier and Tunç Hussein (2008) found that $8.7 \%$ of the hotels do not have a cleaning warehouse, while $99.3 \%$ of the employees in food and beverage businesses never store cleaning materials and food in the same place in their study. Among the statements about the kitchen and equipment after the lesson, the rate of correct answers to the statement about the storage of cleaning materials is at the lowest level (88.2\%). This has led to the conclusion that it is necessary to focus on the issues of chemical hazard contamination of food and to evaluate the possibilities for possible chemical contamination.

There may be poor hygiene conditions due to usage patterns at the service stage of food. Equipment used during service should be handled by the handles, and the surface that will come into contact with food should not be touched. Spoon, fork, and knife sets should be carried in a clean cloth, on the tray or on the serving plate, and not with bare hands (Artik et al., 2017). The finding in this area is that while only $83.3 \%$ of the students knew that forks, spoons, and knives should not be held by the mouthparts during service, this rate increased to $93.1 \%$ after the training.

\subsection{Contamination}

Food hazards can be contaminated directly or indirectly to the food and beverages through various sources. Informing food employees and managers about contamination is one of the important steps for food safety. In this context, information on possible contamination and cross-contamination in the kitchen and in the service was also questioned. $85.3 \%$ of the students knew that preparations of different food groups such as meat, vegetables, and pastries should be made on separate counters. In a similar question for cookery students in Turkey, $60.1 \%$ of the students knew that it is unsafe for meat and vegetables to be chopped up on the same cutting board (Giritlioğlu et al., 2011). Another finding of our study is that $23.5 \%$ of the students thought that they could heat the unconsumed meals and serve them again. Although contamination and cross-contamination prevention measures are much better known, the inconveniences of re-serving the food and the effect of possible contamination are not still understood by some of the students $(12.7 \%)$ after taking the lesson.

Raw and cooked foods should be prepared in a way that they do not come into contact with each other and then kept separate from each other in a way to prevent cross-contamination. $86.3 \%$ of the students had knowledge about not storing raw and cooked foods together. In a study on food safety among university students from different disciplines in Saudi Arabia, only $78.3 \%$ of females and $50.9 \%$ of male students knew that cooked and uncooked food should not be stored in the same refrigerator (Al-Shabib, Husain and Khan, 2017). Except for the question of reheating and serving the food again, over $94 \%$ of students answered the questions about contamination and cross-contamination correctly after the training. All students have learned that the preparation of raw and cooked foods should be done on separate counters and that previously cooked meals should not be mixed with newly cooked meals. 


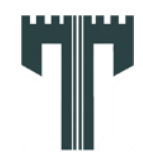

Gastroia: Journal of Gastronomy and Travel Research, Vol. 5, Issue 3, 505-521, 2021

The Effect of Food Safety and Hygiene Education on the Knowledge Levels of Tourism Students Öznur CUMHUR

\subsection{Temperature Control and Food Preservation}

The progress of different food and beverages towards service in the kitchen is different from each other. In this process, any food is exposed to different temperatures and times by cooking, cooling, freezing, thawing, and waiting until it is served. Lack of knowledge of the temperatures to which food is exposed leads to the multiplication of bacterial pathogens and survival in food and the development of foodborne diseases (Shapiro et al., 1999). From the results obtained in this group, it was revealed that there was a lack of knowledge in this area. "Although the lack of knowledge on this group has been a bit eliminated after taking the lesson, it has still maintained the lowest food safety knowledge (90.2\%). This situation reveals the lack of knowledge of the students although they pass the course and it becomes a worrying situation regarding food poisoning. Similarly, Hertzman et al. (2011) showed that food safety education increased some food safety knowledge but detected that most students failed to recognize proper temperatures for food preparation, reheating, and serving. In another study of food safety knowledge among food handlers in three European countries, it was found that the lowest information was available on the adequate temperature for cooking, storing, and holding food (Smigic et al., 2016). Similarly, Baş et al. (2006) reported that food processors in food handlers in Turkey lack information about critical temperatures. For these reasons and determinations, temperature control should be emphasized in all kinds of food safety education for the control of foodborne diseases and it is beneficial to diversify and increase the examples related to possible scenarios in the food chain.

In addition to Table 2, the number of students who gave correct answers about the temperature control and food preservation knowledge group is given in the graphic in Figure 1. In this study, $89.2 \%$ of the student knew that cold foods such as milk desserts should be kept below $10^{\circ} \mathrm{C}$, while only $75.5 \%$ of the students knew that hot meals should be kept at least $65^{\circ} \mathrm{C}$ until or during service. One of the most important findings in this study was that only a very small percentage of the students $(20.6 \%)$ knew that frozen foods should not be thawed at ambient temperature by placing them on the kitchen counter. Similarly, studies conducted with university students in China (Luo et al., 2019) and cookery students in Turkey (Giritlioğlu et al., 2011), it was revealed that the level of knowledge about thawing frozen foods was low at $42 \%$ and $29.3 \%$, respectively. In a study conducted by Başer et al. (2016), only $45.9 \%$ of the service and kitchen staff working in 4-5 star hotels in Turkey know the correct application of thawing frozen foods. 
Gastroia: Journal of Gastronomy and Travel Research, Vol. 5, Issue 3, 505-521, 2021

The Effect of Food Safety and Hygiene Education on the Knowledge Levels of Tourism Students Öznur CUMHUR

$\begin{array}{rcc}\text { Frozen foods should be stored at }-18^{\circ} \mathrm{C} . & 89 & 96 \\ \text { Frozen food can be defrosted on the... } & 21 & 73 \\ \text { Frozen food can be refrozen after... } & 89 & 100 \\ \text { Microorganisms are killed by freezing.. } & 56 & 78 \\ \text { Refrigerator temperature slows down the... } & 80 & 98 \\ \text { Cold foods such as milk desserts should... } & 91 & 93 \\ \text { Egg foods, dairy foods, meat, and meat... } & 86 & 92 \\ \text { Hot meals should be kept at a... } & 77 & 98 \\ \text { Pasteurization and sterilization are the... } & 88 & 100 \\ \text { Number of students who answered correctly } \\ \text { before the lesson }\end{array}$

Figure 1. The number of students who gave correct answers to the temperature control and food preservation knowledge group $(n=102)$

Other findings obtained in the study were that $87.3 \%$ of the students knew that the frozen foods should be stored at $-18{ }^{\circ} \mathrm{C}$ and that frozen food should not be re-frozen after dissolving. However, almost half of the students $(45.1 \%)$ stated the incorrect opinion that ice cream kills microorganisms, whereas $78.4 \%$ of the students were correct that the refrigerator slowed microbial growth. About this subject, only $11 \%$ of university students in Sweden (Marklinder et al., 2020) and 64\% of university students in Lebanese (Hassan and Dimassi, 2014) knew that the bacteria would not be killed by freezing. After taking the lesson, $96.1 \%$ of the tourism management students learned the effect of the refrigerator, while $76.5 \%$ of them learned the effect of freezing. Students had a better understanding of the effect of refrigerator on microbial activity than the effect of freezing on microbial activity. However, almost $1 / 4$ of the students still do not understand the effect of freezing on microbial activities.

It has been determined that students' views on critical temperatures, freezing and thawing of foods, which will determine their attitudes in food preparation and processing practices, are not clear enough and there is a lack of knowledge on these issues. When evaluated in general, although the average level of knowledge increased by $22.4 \%$ after the food safety and hygiene lesson, it was concluded that more emphasis should be placed on temperature applications in the food production process, food preservation methods, and food processing in food safety education.

\section{CONCLUSION}

The key to ensuring food safety in tourism is to train and use trained and qualified personnel in the relevant field. With the information obtained from this research, knowledge gaps in some critical areas of food safety and hygiene for tourism undergraduate students have been identified especially before education. Present study showed that with a lesson like food safety and hygiene, deficiencies in food safety information can be overcome. At this point, within the scope of the training, it has come to the forefront to fill the identified gaps by focusing especially on temperature control, food processing and food preservation, and to 
Gastroia: Journal of Gastronomy and Travel Research, Vol. 5, Issue 3, 505-521, 2021

The Effect of Food Safety and Hygiene Education on the Knowledge Levels of Tourism Students Öznur CUMHUR

combine the messages on contamination with practical examples. In this direction, training materials focused on these critical issues should be created.

One of the effective ways to ensure food safety is to include such lessons in current education programs. Thus, teaching lessons aimed at improving the knowledge and awareness of tourism management students on hygiene and food safety can be used as a tool for risk communication and eliminating deficiencies. This is especially important in reducing the risk of food poisoning. It is important to improve the training content and evaluate its reflection on the sector by evaluating the feedback of such studies and active field studies and the reasons for the occurrence of foodborne diseases. There should be a partnership between departments such as tourism management in universities where food contact workers are trained and the food and beverage industry and the evaluation of the training given in the relevant departments to ensure food safety and protect public health should be continued.

The practical equivalent of food safety education was not evaluated in this study and the data were obtained from self-declared results. In addition, this study is limited to a sample of students from only one university. In future studies, the sampling area can be expanded and the knowledge of students from different universities can be compared. Future research should also focus on the reflection of food safety education on behavioural development, conducting observational studies, its counterpart in the industry, and the extent to which the tourism industry offers these practices.

\section{REFERENCES}

Al-Shabib, N. A., Husain, F. M. and Khan, J. M., (2017). Study on food safety concerns, knowledge and practices among university students in Saudi Arabia. Food Control, 73, 202-208.

Artık, N., Şanlıer, N. and Sezgin, A.C., (2017). Gıda güvenliği ve gıda mevzuatı (1. Baskı). Ankara: Detay Yayınc1lık.

Baş, M., Ersun, A. Ş. and Kıvanç, G., (2006). The evaluation of food hygiene knowledge, attitudes, and practices of food handlers' in food businesses in Turkey. Food Control, 17(4), 317e322.

Başer, F., Abubakirova, A., Şanlıer, N., Çil, B. (2016). 4-5 yıldızlı otellerdeki servis ve mutfak personellerinin gıda güvenliğine ilişkin bilgi, tutum ve davranışları: Türkiye ve Kazakistan karş1laştırması. Seyahat ve Otel İşletmeciliği Dergisi, 13(3), 23-37.

Çebi, K., Özyürek, S. and Türkyılmaz, D. (2018). Süt ve süt ürünleri tüketiminde tüketici tercihlrini etkileyen faktörler: Erzincan ili Örneği. Yüzüncü Yll Üniversitesi Tarım Bilimleri Dergisi, 28(1), 70-77.

Centers for Disease Control and Prevention. (2017). Surveillance for foodborne disease outbreaks, United States, 2017: Annual peport. Atlanta, Georgia: U.S. Department of Health and Human Services. Retrieved https://www.cdc.gov/fdoss/pdf/2017_FoodBorneOutbreaks_508.pdf

Clayton, M. L., Clegg Smith, K., Neff, R. A., Pollack, K. M. and Ensminger, M., (2015). Listening to food workers: Factors that impact proper health and hygiene 


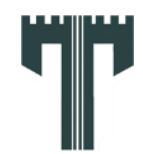

Gastroia: Journal of Gastronomy and Travel Research, Vol. 5, Issue 3, 505-521, 2021

The Effect of Food Safety and Hygiene Education on the Knowledge Levels of Tourism Students Öznur CUMHUR

practice in food service. International Journal of Occupational and Environmental Health, 21(4), 314-327.

Council of Higher Education, (2020). Higher Education Information Management System. Retrieved from https://istatistik.yok.gov.tr/

Ertopcu, İ., Avcıkurt, A. and Çetinkaya, T. (2019). Aşçılık programı öğrencilerinin hijyen bilgi düzeyleri üzerine bir araştırma. Journal of Tourism and Gastronomy Studies, 7(3), 2187-2203.

European Food Safety Authority and European Centre for Disease Prevention and Control. (2019). The European union one health. 2018 zoonoses report. Retrieved from https://www.ecdc.europa.eu/sites/default/files/documents/zoonoses-EU-one-health2018-report.pdf

Fraser, A. M. and Miller, C., (2014). Educating for food safety. In R. Bhat and V. M. GómezLópez (Eds.), Practical food safety: Contemporary issues and future directions (pp. 3148). Wiley-Blackwell.

Giritlioğlu, I., Batman, O. and Tetik, N., (2011). The knowledge and practice of food safety and hygiene of cookery students in Turkey. Food Control, 22, 838-842.

Gould, H. L., Rosenbulum, I., Nicholas, D., Phan, Q. and Jones, T. F., (2013). Contributing factors in restaurant-associated foodborne disease outbreaks, FoodNet Sites, 2006 and 2007. Journal of Food Protection, 76 (11), 1824-1828.

Hassan, H. F. and Dimassi, H., (2014). Food safety and handling knowledge and practices of Lebanese university students. Food Control, 40, 127-133.

Hertzman, J. L., Kitterlin, M., Farrish, J. and Stefanelli, J., (2011). The effect of food safety education and work experience on knowledge, attitudes, and practices of university students. Journal of Hospitality \& Tourism Education, 23(1), 18-27.

Jackson-Davis, A., Olsen, S., Chapman, B., Raymond, B. and Chaifetz, A., (2015). Approaches to food safety education among critical groups. In S. C. Ricke, J. R., Donaldson and C. A., Philips (Eds.), Food safety emerging issues, technologies and systems (pp. 347-364). London: Academic Press.

Lange, M., (2017). Food safety learning in home and consumer studies: Teachers' and students' perspectives. PhD Thesis. Uppsala University, Uppsala.

Luo, X., Xu, X., Chen, H., Bai, R., Zhang, Y., Hou, X., ...Zhao, Y., (2019). Food safety related knowledge, attitudes, and practices (KAP) among the students from nursing, education and medical college in Chongqing, China. Food Control, 95, 181-188.

Marklinder, I., Ahlgren, R., Blücher, A., Ehn Börjesson, S. M., Hellkvist, F., Moazzami, M., ...Danielsson-Tham, M. L., (2020). Food safety knowledge, sources thereof and selfreported behaviour among university students in Sweden. Food Control, 107130.

Mert, İ., Artık, N., Dellal, G. and Şireli, U.T. (2020). Süt kalitesi ve süt-sağlık ilişkisi. Ulusal Süt Konseyi. Retrieved from https://ulusalsutkonseyi.org.tr/wpcontent/uploads/sut_kalitesi_A5_bask__.pdf 
Gastroia: Journal of Gastronomy and Travel Research, Vol. 5, Issue 3, 505-521, 2021

The Effect of Food Safety and Hygiene Education on the Knowledge Levels of Tourism Students Öznur CUMHUR

Ozilgen, S., (2011). Food safety education makes the difference: Food safety perceptions, knowledge, attitudes and practices among Turkish university students. Journal of Consumer Protection and Food Safety, 6, 25-34.

Sanlier, N., Cömert, M. and Durlu-Özkaya, F., (2010). Hygiene perception conditions of hotel kitchen staff in Ankara, Turkey. Food Science and Technology Research, 30, 415431.

Sanlıer, N., Sormaz, Ü. and Güneş, E., (2020). The effect of food safety education on food safety knowledge, attitudes, behaviors of individuals who work in food and beverage departments in Turkey. International Journal of Gastronomy and Food Science, 22, 100259.

Sanlıer, N. and Tunç Hussein, A. (2008). Yiyecek - içecek hizmeti veren otel mutfakları ve personelinin hijyen yönünden değerlendirilmesi: Ankara ili örneği, Kastamonu Eğitim Dergisi, 16(2), 461-468.

Scheule, B., (2000). Food safety educational goals for dietetics and hospitality students. Journal of the American Dietetic Association, 100(8), 919-927.

Shapiro, R., Ackers, M. L., Lance, S., Rabbani, M., Schaefer, L., Daugherty, J., ... Swerdlow, D., (1999). Salmonella Thompson associated with improper handling of roast beef at a restaurant in Sioux Falls, South Dakota. Journal of Food Protection, 62(2), 118-22.

Smigic, N., Djekic, I., Martins, M. L., Rocha, A., Sidiropoulou, N. and Kalogianni, E. P., (2016). The level of food safety knowledge in food establishments in three European countries. Food Control, 63, 187-194.

Stratev, D., Odeyemi, O. A., Pavlov, A., Kyuchukova, R., Fatehi, F. and Bamidele, F. A., (2017). Food safety knowledge and hygiene practices among veterinary medicine students at Trakia University, Bulgaria. Journal of Infection and Public Health, 10(6), $778-782$.

Tuncer, A. and Akoğlu, A., (2020). Food safety knowledge of food handlers working in hotel kitchens in Turkey. Food and Health, 6(2), 77-89.

Ünlüönen, K. and Cömert, M., (2013). Otel işletmeleri mutfak çalışanlarının personel hijyeni bilgi düzeylerinin belirlenmesi, Journal of Tourism and Gastronomy Studies, 312.

World Health Organization. (2004). Surveillance programmed for control of food borne infections and toxications in Europe. 8th Report 1999-2000, Country Report Turkey, Geneva.

World Health Organization. (2017). Food safety key facts. Retrieved from http://www.who.int/news-room/fact-sheets/detail/food-safety 